\title{
CEP350 Gene
}

National Cancer Institute

\section{Source}

National Cancer Institute. CEP350 Gene. NCI Thesaurus. Code C131272.

This gene is involved in anchoring microtubules to the centrosome. 